\title{
Determination of Ideal Cooking Conditions for Pulp Production from Avocado Wood (Persea americana Mill.) by Kraft Method
}

\section{Određivanje idealnih uvjeta kuhanja u proizvodnji pulpe od drva avokada (Persea americana Mill.) primjenom kraft metode}

\author{
Preliminary paper • Prethodno priopćenje \\ Received-prispjelo: 7. 12. 2020. \\ Accepted-prihvaćeno: 26. 5. 2021. \\ UDK: $630 * 861.311 ; 630 * 862.2$ \\ https://doi.org/10.5552/drvind.2021.2048
}

\begin{abstract}
In this study, hand sheets were made from pulp produced by the Kraft method using avocado wood. The raw materials were supplied by a fruit orchard and consisted of avocado (Persea americana Mill.) trees that had completed their useful life and were cut during routine thinning maintenance. In order to determine the ideal cooking conditions in the production of pulp from avocado wood via the Kraft method, 16 cooks were carried out by varying the cooking time (T), active alkali (AA), and sulfidity (S) ratios. The general pulp properties, especially the screened pulp yield, pulp viscosity, and Kappa number, were evaluated. The pulp yield was taken as the primary basis in determining the cooking conditions. The ideal cooking conditions were also determined by considering some physical, mechanical, and optical properties of the paper. According to this study, the conditions found to be ideal in pulp production from avocado (Persea americana Mill.) wood via the Kraft method were: 18 $\% A A, 22 \% S$, and $75 \min T$.
\end{abstract}

Keywords: avocado wood (Persea americana Mill.); Kraft method; pulp/paper production; pulp/paper properties

SAŽETAK • U ovom su istraživanju izrađeni eksperimentalni papiri od pulpe dobivene sulfatnim (kraft) postupkom od drva avokada. Kao sirovina za proizvodnju pulpe odabrano je drvo avokada (Persea americana Mill.) iz plantažnog uzgoja, posječeno tijekom rutinskog prorjeđivanja nakon završetka životnog vijeka stabla. Radi utvrđivanja idealnih uvjeta kuhanja u proizvodnji pulpe od drva avokada kraft metodom, provedeno je 16 kuhanja, pri čemu su varirani omjeri vremena kuhanja (T), dodatka lužine (AA) i sulfidnost (S). Utvrđena su opća svojstva dobivene pulpe, uz naglasak na prinos prosijane pulpe, njezinu viskoznost $i$ vrijednost kappa broja. Prinos pulpe pritom je uzet kao primarni podatak za određivanje uvjeta kuhanja. Idealni uvjeti kuhanja također su utvrđeni uključivanjem nekih fizikalnih, mehaničkih i optičkih svojstava papira. Prema ovom istraživanju, idealni uvjeti za proizvodnju pulpe od drva avokada (Persea americana Mill.) kraft metodom jesu: $A A=18 \%, S=22 \%$ i $T=75$ min.

Ključne riječi: drvo avokada (Persea americana Mill.); kraft metoda; proizvodnja pulpe/papira; svojstva pulpe/ papira

${ }^{1}$ Authors are researchers at Bartin University, Faculty of Forestry, Forest Industrial Engineering, Bartin, Turkey. 


\section{INTRODUCTION}

\section{UVOD}

Many types of trees, bushes, and vines are cultivated for fruit production around the world. Although their useful lives and productive periods vary according to the species, some trees require frequent pruning and others require early replacement because of their short span of productivity. For whatever reason, at certain periods a significant biomass supply is available from orchards. Using this potential in the forest industry reduces the pressure on the essential forest trees. Therefore, the issue of utilizing fruit tree wood has attracted the attention of researchers working in the forest industry. For example, in a study conducted in Poland, it was stated that if the residues remaining from the maintenance pruning carried out every year in a 100-ha apple orchard were burned and converted into energy, the net present value of the total income obtained in 10 years would be $€ 5644$ (Arkadiusz et al., 2020). In a study conducted in Turkey, the physical and mechanical properties of the trunk wood of dateplum, olive, and loquat trees were examined and it was reported that they could be used in woodturning, carving, and toy production and in the production of massive furniture elements that require high resistance and durability (Topaloğlu and Ustaömer, 2020). A number of studies have investigated the suitability of fruit trees for pulp production. Included among those evaluated have been pomegranate prunings (Gülsoy et al., 2015), white mulberry (Gençer et al., 2013), common hazelnut (Gençer and Özgül, 2015, 2016), kiwi (Gençer, 2015), wild cherry (Gençer and Gül Türkmen, 2016), wild dogwood (Gençer and Aksoy, 2017), apricot (Gençer et al., 2018), date-plum, olive, and loquat (Topaloğlu et al., 2019). Most of these types were found to be suitable for pulp production, whereas some were not. For example, Topaloğlu et al. (2019) suggested that olive trunk wood was suitable for pulp production, but date-plum and loquat wood should be put to other uses. Similarly, it was suggested that apricot wood was suitable for pulp production, but fruit pericarp should be used in the board industry (Gençer et al., 2018). It has been stated that the wood of the olive (Olea europaea L.) and fig (Ficus carica) trees is similar to that of broad-leaved trees in terms of their chemical components (Odabaş Serin and Kılıç Penezoğlu, 2020a, 2020b). It has been reported that the pulp yields obtained from orange tree (González et al., 2011) and kiwi pruning residues (Gençer, 2015) can be used to manufacture paper pulp with satisfactory yields.

In a study conducted on avocado wood, branches were found to have significant biomass potential, but without treatment, it is weak in an outdoor environment because certain of its mechanical and physical properties are low. However, it was recommended for furniture production and indoor use (Fuentes-Talavera et al., 2011). The specific gravity of avocado branch wood was found to be (air dry) $0.54 \mathrm{~g} \mathrm{~cm}^{-3}$ at $12 \%$ moisture content and the density to vary from low to medium (Fuentes-Talavera et al., 2011). This type of wood, of medium density and with flexible fibers (K1rc1, 2000), can be utilized in pulp production. Runkel ratio shows the collapsibility of the fibers. Collapsed fibers have high fiber bonding area. Therefore, fibers having Runkel ratio of 1 or less are good for papermaking. Runkel ratio of Persea americana was 0.95 (Ajuziogu et al., 2010). In addition, it was stated that avocado wood is suitable for pulp production using chemical methods and that the resulting pulp is easy to bleach (Vargas et al., 2006). These sample studies demonstrate that it is possible to obtain the maximum benefit from a raw material by carrying out research to find its correct application areas.

Avocado (Persea americana Mill.) belongs to the Lauraceae family. In well-maintained orchards where it is grown, a height of 10-15 m and diameter of 40-60 $\mathrm{cm}$ are considered ideal in terms of fruit yield. In mixed stands in its natural environment, its height can reach 25-30 m. Although this species is native to Mexico and Central America, some species are commonly grown in many countries having a Mediterranean climate. In our country, avocado is produced in significant amounts in the Mediterranean Region, including the provinces of Antalya, Mersin, and Muğla (Demirkol, 2001; Bayram et al., 2006). The Fuerte variety of avocado (Persea americana Mill.) is grown in the Gazipaşa district of Antalya Province and trees past the age of useful fruit production were used as the wood raw material in the study. The Kraft method has been reported to be suitable for all types of raw materials in pulp production (Rydholm, 1965). Based on this literature review, the aim of this study was to produce pulp from avocado wood using the Kraft method.

\section{MATERIALS AND METHODS} 2. MATERIJALI I METODE

\subsection{Materials}

2.1. Materijali

The avocado (Persea americana Mill.) trunk used in this study was obtained from an orchard at an altitude of 4 to $5 \mathrm{~m}$ from the sea in Gazipaşa District of Antalya Province, Turkey. The study used trunk wood of 15-year-old Fuerte species trees that the grower had decided to cut during thinning maintenance. Wood discs (10 cm thickness) were taken from bottom, middle, and top of the trunk. These discs were debarked and subdivided into two discs ( $5 \mathrm{~cm}$ thickness). The wood samples were chipped manually for pulping. The chip size was about $50 \mathrm{~mm} \times 15 \mathrm{~mm} \times 5 \mathrm{~mm}$ (length $\times$ width $\times$ thickness). The chemical composition and fiber morphology of avocado wood were determined in our previous study (Altunışık Bülbül and Gençer, 2021). The holocellulose, $\alpha$-cellulose, klason lignin, hot water solubility, cold water solubility, $1 \% \mathrm{NaOH}$ solubility, and ethanol solubility of avocado wood were $73.29 \%, 55.05 \%, 14.85 \%, 2.64 \%, 1.51 \%$, $19.75 \%$, and $4.50 \%$, respectively. Fiber length, fiber width, lumen width, cell wall thickness, slenderness ratio, flexibility ratio, and Runkel ratio of avocado 
wood were $1.06 \mathrm{~mm}, 25.78 \mu \mathrm{m}, 16.18 \mu \mathrm{m}, 4.80 \mu \mathrm{m}$, 41.0, 63.0, and 0.59, respectively.

\subsection{Methods
2.2. Metode}

By changing the cooking time (T), active alkali (AA) ratio, and sulfidity $(\mathrm{S})$, a total of 16 cooks divided into four groups (A, B, C, D) were completed via the Kraft method using the avocado wood. The cooking time was $75 \mathrm{~min}$ for the groups $\mathrm{A}$ and $\mathrm{C}$ and $90 \mathrm{~min}$ for the groups B and D. The active alkali was used in two different ratios: $18 \%$ for the groups $\mathrm{A}$ and $\mathrm{B}$ and $20 \%$ for the groups $\mathrm{C}$ and $\mathrm{D}$. In each group, four different cooks were carried out by changing the sulfidity rate (20\%, $22 \%, 24 \%$, and $26 \%$ ). The cooking temperature of softwood chips should be $170^{\circ} \mathrm{C}$ and above for pulp production using the Kraft method. However, as there is less lignin in hardwood, $160-170{ }^{\circ} \mathrm{C}$ is ideal (Rydholm, 1965). Therefore, using the Kraft method, pulp was produced from the avocado wood at a cooking temperature of $165^{\circ} \mathrm{C}$ for $90 \mathrm{~min}$.

Avocado wood has been reported to be more easily cooked than other hardwoods such as eucalyptus (Vargas et al., 2006). Based on this literature review, the targeted cooking temperature was set as $165^{\circ} \mathrm{C}$. In addition, the study investigated the effects on the yield of reducing the cooking time to $75 \mathrm{~min}$. Pulp production was carried out in an electrically heated laboratory-type cooking vessel at $165 \pm 3{ }^{\circ} \mathrm{C}$, with a pressure of $25 \mathrm{~kg} \mathrm{~cm}^{-2}$, a capacity of $15 \mathrm{~L}$, and at 2 cycles per minute. It was stated that no significant change in pulp yield would occur in the range of $150-170{ }^{\circ} \mathrm{C}$ at the least, provided that a regular preheating time and temperature were maintained (Rydholm, 1965). For this reason, the time to reach the maximum temperature in all cooks was kept constant (60 $\mathrm{min}$ ) and care was taken to keep the vessel temperature below $150{ }^{\circ} \mathrm{C}$ until the fiftieth minute of the preheating time. The period for reaching the maximum temperature began after the fiftieth minute, and the maximum temperature was reached in the 60th minute. The pulpcooking plan for the avocado (Persea americana Mill.) wood using the Kraft method is outlined in Table 1.

The total yield was calculated from the pulp washed after the cooking processes listed in Table 1. The fibers released in the mixer were screened in a Somerville vibratory vacuum sieve according to TAPPI T 275 sp-02 (2002) standard and after the residue was separated, the screened pulp yield was calculated according to TAPPI 412 om-02 (2002) standard. Screened pulps were beaten up to $(36 \pm 4) \mathrm{SR}^{\circ}$ in a Hollander beater according to TAPPI T200 sp-01 (2001) standard. The degree of freedom of the pulps was determined on a Schopper-Riegler device according to the ISO 5267-1:2012 standard. Values for the Kappa number and viscosity were determined according to TAPPI T 236 om-06 (2006) and SCAN-CM 15-62 (1962) standards, respectively. Ten handsheets of $(75 \pm 2) \mathrm{g} / \mathrm{m}^{2}$ in weight were produced from these pulps according to ISO 5269-2:2013 standard.

After conditioning the handsheets at $(23 \pm 2){ }^{\circ} \mathrm{C}$ and $(50 \pm 2) \%$ relative humidity for $24 \mathrm{~h}$ in accordance
Table 1 Kraft method pulp cooking plan for avocado wood Persea americana Mill.)

Tablica 1. Plan kuhanja pulpe od drva avokada (Persea americana Mill.) prema kraft metodi

\begin{tabular}{|c|c|c|c|}
\hline $\begin{array}{c}\text { Cook group } \\
\text { No. } \\
\begin{array}{c}\text { Br. kuhane } \\
\text { skupine }\end{array}\end{array}$ & $\begin{array}{c}\text { Active } \\
\text { alkali, \% } \\
\text { Aktivna } \\
\text { lužina, \% }\end{array}$ & $\begin{array}{c}\text { Sulfidity, } \\
\text { \% } \\
\text { Sulfidnost, } \\
\%\end{array}$ & $\begin{array}{c}\text { Cooking time at } \\
\text { max. tempera- } \\
\text { ture, min } \\
\text { Vrijeme kuhanja } \\
\text { pri najvišoj } \\
\text { temperaturi, min }\end{array}$ \\
\hline A1 & 18 & 20 & 75 \\
\hline A2 & 18 & 22 & 75 \\
\hline A3 & 18 & 24 & 75 \\
\hline A4 & 18 & 26 & 75 \\
\hline B1 & 18 & 20 & 90 \\
\hline B2 & 18 & 22 & 90 \\
\hline B3 & 18 & 24 & 90 \\
\hline B4 & 18 & 26 & 90 \\
\hline C1 & 20 & 20 & 75 \\
\hline C2 & 20 & 22 & 75 \\
\hline C3 & 20 & 24 & 75 \\
\hline C4 & 20 & 26 & 75 \\
\hline D1 & 20 & 20 & 90 \\
\hline D2 & 20 & 22 & 90 \\
\hline D3 & 20 & 24 & 90 \\
\hline D4 & 20 & 26 & 90 \\
\hline & & & \\
\hline
\end{tabular}

with TAPPI T 402 sp-03 (2003) standard, they were evaluated to determine opacity TAPPI T 519 om-02 (2002), brightness TAPPI T 525 om-02 (2002), tear index TAPPI T 414 om-98 (1998), tensile index TAPPI T 494 om-01 (2001), and burst index TAPPI T 403 om02 (2002) according to relevant standards. Elongation and TEA values were also determined while performing the tensile test.

\section{RESULTS AND DISCUSSION} 3. REZULTATI I RASPRAVA

Some of the obtained pulp properties, the brightness and opacity values of the paper produced from these pulps, are given in Table 2.

Dissolution and degradation of carbohydrates develops independently of sulfidity in the cooking solution. Therefore, there was no significant change in viscosity with the increase of sulfidity within the groups. However, the concentration of sodium hydroxide is highly related to cooking time and temperature. In this study, in the cooking of groups where the active alkali ratio was increased ( $A$ and $\mathrm{C}$ ), the decrease in viscosity was more effective than the increase in processing time. Here, the ineffectiveness of the time period was due to the low cooking temperature. However, it is certain that at high temperatures, extension of the time period would have increased the alkali degradation. In this case, a low alkali rate was more advantageous. Alkaline degradation of hemicelluloses, which is more important for their strength properties, is not necessarily parallel to cellulose degradation, but it is likely to develop slightly later. The effect of removing lignin in 
Table 2 Some properties of avocado (Persea americana Mill.) wood Kraft pulps and brightness and opacity values of the paper produced from them

Tablica 2. Neka svojstva kraft pulpe od drva avokada (Persea americana Mill.) i vrijednosti svjetline i neprozirnosti papira proizvedenoga od nje

\begin{tabular}{|c|c|c|c|c|c|c|c|}
\hline $\begin{array}{c}\text { Groups-AA, } \\
\%-T, \text { min }^{\mathbf{a}} \\
\text { Grupe - AA, } \\
\%-T, \min ^{\mathrm{a}}\end{array}$ & $\begin{array}{l}\text { Cook No.- } \\
\text { Sulfidity, \% } \\
\text { Br. kuhanja - } \\
\text { sulfidnost, \% }\end{array}$ & $\begin{array}{c}\text { Screened yield, } \\
\% \\
\text { Prinos } \\
\text { prosijavanja, \% }\end{array}$ & $\begin{array}{c}\text { Reject, } \\
\text { \% } \\
\text { Škart, \% }\end{array}$ & $\begin{array}{c}\text { Viscosity, } \\
\mathbf{c m}^{3} / \mathbf{g}^{1} \\
\text { Viskoznost, } \\
\mathrm{cm}^{3} / \mathrm{g}\end{array}$ & $\begin{array}{c}\text { Kappa } \\
\text { No. } \\
\text { Kappa } \\
\text { broj } \\
\end{array}$ & $\begin{array}{c}\text { ISO } \\
\text { Brightness, \% } \\
\text { ISO svjetlina, } \\
\% \\
\end{array}$ & $\begin{array}{c}\text { ISO } \\
\text { Opacity, \% } \\
\text { ISO } \\
\text { neprozirnost, \% }\end{array}$ \\
\hline \multirow{4}{*}{ A-18-75 } & A1-20 & 45.46 & 0.25 & 1418 & 25.91 & 19.84 & 99.78 \\
\hline & A2-22 & 47.25 & 0.33 & 1413 & 24.81 & 19.35 & 99.82 \\
\hline & A3-24 & 47.21 & 0.21 & 1413 & 23.50 & 19.01 & 99.87 \\
\hline & A4-26 & 46.73 & 0.31 & 1410 & 22.30 & 18.52 & 99.92 \\
\hline \multirow{4}{*}{ B-18-90 } & B1-20 & 45.06 & 0.23 & 1413 & 18.84 & 18.44 & 99.92 \\
\hline & B2-22 & 45.46 & 0.17 & 1405 & 18.46 & 18.42 & 99.93 \\
\hline & B3-24 & 46.70 & 0.08 & 1405 & 18.40 & 17.78 & 99.93 \\
\hline & B4-26 & 46.33 & 0.05 & 1400 & 18.32 & 17.56 & 99.96 \\
\hline \multirow{4}{*}{ C-20-75 } & $\mathrm{C} 1-20$ & 46.39 & 0.18 & 1356 & 20.05 & 18.88 & 99.86 \\
\hline & $\mathrm{C} 2-22$ & 46.86 & 0.03 & 1356 & 19.97 & 18.71 & 99.92 \\
\hline & C3-24 & 46.30 & 0.03 & 1350 & 19.46 & 17.72 & 99.92 \\
\hline & $\mathrm{C} 4-26$ & 44.97 & 0.05 & 1345 & 18.98 & 17.64 & 99.96 \\
\hline \multirow{4}{*}{ D-20-90 } & D1-20 & 43.11 & 0.03 & 1345 & 18.79 & 18.52 & 99.87 \\
\hline & D2-22 & 44.28 & 0.16 & 1355 & 18.02 & 18.18 & 99.89 \\
\hline & D3-24 & 45.85 & 0.14 & 1350 & 18.42 & 17.51 & 99.90 \\
\hline & D4-26 & 45.93 & 0.08 & 1286 & 18.92 & 17.31 & 99.90 \\
\hline
\end{tabular}

${ }^{a} \mathrm{AA}$ - Active alkali; T - Cooking time at maximum temperature / AA - aktivna lužina; T-vrijeme kuhanja na najvišoj temperaturi

unbleached Kraft pulps is to reduce the strength properties, even at high viscosity (Rydholm, 1965). Although the viscosity was high in group A, low tensile strength resulted because the lignin remaining in the pulp impeded the inter-fiber bonds. A high dose of active alkali at a constant cooking time and temperature greatly lowers viscosity, whereas changes in sulfidity have only a minor effect. This is because of the absence of a significant change in viscosity within the groups at a constant active alkali and cooking time.
Opacity is important for writing and printing paper and is advantageous because paper with high opacity can be used on both sides. The opacity value increased in the groups with a long cooking time and with the increase of sulfidity within the groups. Rydholm (1965) stated that high opacity was especially important in paper produced for printing. Most bleachable sulfate pulps are cooked to 14-18 Kappa numbers. Pulps obtained from deciduous wood can be bleached to brightness values of up to 70 without decreasing the

Table 3 Some properties of paper from avocado (Persea americana Mill.) wood kraft pulps according to $36 \mathrm{SR}^{\circ}$ Tablica 3. Neka svojstva papira od kraft pulpe drva avokada (Persea americana Mill.) prema $36 \mathrm{SR}^{\circ}$

\begin{tabular}{|c|c|c|c|c|c|c|}
\hline $\begin{array}{c}\text { Groups-AA, } \% \\
-\boldsymbol{T}, \min * \\
\text { Grupe - } A A, \% \\
-T, \text { min* }\end{array}$ & $\begin{array}{l}\text { Cook No.- } \\
\text { Sulfidity, \% } \\
\text { Br. kuhanja- } \\
\text { sulfidnost, \% }\end{array}$ & $\begin{array}{c}\text { Tensile } \\
\text { index, } \mathbf{N} \cdot \mathbf{m} / \mathbf{g} \\
\text { Vlačni indeks, } \\
\mathrm{N} \cdot \mathrm{m} / \mathrm{g}\end{array}$ & $\begin{array}{l}\text { Elongation, \% } \\
\text { Produljenje, \% }\end{array}$ & $\operatorname{TEA}^{\mathrm{b}}, \mathbf{j} / \mathbf{m}^{2}$ & $\begin{array}{c}\text { Tear index, } \\
\mathbf{m} \cdot \mathbf{N} \cdot \mathbf{m}^{2} / \mathbf{g} \\
\text { Indeks kidanja, } \\
\mathrm{m} \cdot \mathrm{N} \cdot \mathrm{m}^{2} / \mathrm{g}\end{array}$ & $\begin{array}{c}\text { Burst index, } \\
\mathbf{k P a} \cdot \mathbf{m}^{2} / \mathbf{g} \\
\text { Indeks } \\
\text { prskanja, } \\
\mathrm{kPa} \cdot \mathrm{m}^{2} / \mathrm{g} \\
\end{array}$ \\
\hline \multirow{4}{*}{ A-18-75 } & A1-20 & 60.10 & 2.25 & 62.95 & 3.28 & 2.94 \\
\hline & A2-22 & 69.30 & 2.22 & 83.95 & 3.94 & 2.51 \\
\hline & A3-24 & 67.27 & 2.45 & 93.51 & 2.85 & 2.83 \\
\hline & A4-26 & 68.66 & 2.35 & 86.60 & 3.38 & 2.49 \\
\hline \multirow{4}{*}{ B-18-90 } & B1-20 & 70.95 & 2.36 & 92.08 & 3.28 & 2.50 \\
\hline & B2-22 & 73.75 & 2.47 & 97.96 & 2.87 & 2.80 \\
\hline & B3-24 & 70.90 & 2.58 & 96.62 & 3.00 & 2.58 \\
\hline & B4-26 & 63.26 & 2.19 & 76.61 & 2.92 & 2.20 \\
\hline \multirow{4}{*}{ C-20-75 } & C1-20 & 73.47 & 2.47 & 100.00 & 3.57 & 3.27 \\
\hline & $\mathrm{C} 2-22$ & 70.20 & 2.46 & 99.88 & 2.91 & 2.89 \\
\hline & C3-24 & 68.00 & 2.50 & 91.85 & 2.70 & 2.80 \\
\hline & C4-26 & 69.15 & 2.70 & 91.42 & 2.74 & 2.77 \\
\hline \multirow{4}{*}{ D-20-90 } & D1-20 & 75.40 & 2.01 & 78.41 & 3.41 & 2.92 \\
\hline & D2-22 & 73.50 & 2.42 & 99.82 & 3.48 & 2.90 \\
\hline & D3-24 & 73.88 & 2.42 & 105.00 & 3.41 & 2.83 \\
\hline & D4-26 & 73.47 & 2.58 & 103.00 & 3.30 & 2.73 \\
\hline
\end{tabular}

${ }^{\text {aAA }}$ - Active alkali; T - Cooking time at maximum temperature / AA - aktivna lužina; T-vrijeme kuhanja na najvišoj temperaturi

'TEA: tensile energy absorption / apsorpcija vlačne energije 
strength properties (Casey, 1960). The groups in this study, except for group A, can be bleached easily.

The most important characteristic features of paper are achieved by beating the pulp. Some properties of paper improve with beating, whereas some deteriorate. The important thing is to provide the required beating conditions to produce paper with the desired properties. There is an old saying in papermaking: "Paper is made in a beater" (Eroğlu, 1990). This study aimed at $36 \mathrm{SR}^{\circ}$ in the beating process. This was selected because $36 \mathrm{SR}^{\circ}$ is an average beating in which the physical, optical, and mechanical properties do not change excessively. The targeted $\mathrm{SR}^{\circ}$ value was fully realized in some pulps, whereas there were some deviations $\left( \pm 4 \mathrm{SR}^{\circ}\right)$ in others. The values in Table 3 were determined according to pulps corrected to $36 \mathrm{SR}^{\circ}$.

\subsection{Effects of cooking time (T)}

3.1. Učinci vremena kuhanja $(T)$

When the cooking time was examined, the highest screened yield was for $75 \mathrm{~min}$ as seen Table 2 (A2= $47.25 \%$ ). Under these cooking conditions, some of the pulp features were also good. For example, the viscosity of the pulp was high as seen in Table $2(\mathrm{~A} 1=1418$ $\mathrm{cm}^{3} / \mathrm{g}$ ), and the tear and tensile indices of the paper obtained from these pulps were also high. Although the high Kappa number value of these pulps seemed like a disadvantage, they could be bleached if needed. In other words, the important thing is that the pulp did not lose its strength properties.

\subsection{Effects of sulfidity (S)}

3.2. Učinci sulfidnosti (S)

When the cooking conditions were examined, a decrease in the Kappa number was seen within the groups (A,B,C and D, in Table 2) that had an increase in sulfidity at a constant AA ratio and cooking time. This indicated that delignification had increased. The viscosity did not change significantly within the groups because the sodium sulfide protected the cellulose from degradation during cooking.

\subsection{Effects of active alkali (AA)}

\subsection{Učinci aktivne lužine (AA)}

The decrease in the Kappa number occurred because the long cooking time and the high AA ratio directly increased the delignification. Similarly, the decrease in viscosity was due to the destruction of cellulose. Moreover, it is possible to produce paper having different properties from the same pulp since the properties of the pulp can be changed by beating. This provides the paper manufacturer with the opportunity to meet market demands.

\section{CONCLUSIONS}

\section{ZAKLJUČAK}

The most important reason for making use of wood raw materials in pulp production is the high screened yield. In this study, it was observed that, independent of the cooking time and active alkali rate, by increasing the sulfidity rate from $20 \%$ to $22 \%$, there was an increase in the screened yield in all groups, but when it was increased to $24 \%$, there was a decrease in some. Therefore, the sulfidity ratio can be accepted as $22 \%$. Increasing the active alkali rate from $18 \%$ to 20 $\%$, while keeping the cooking time and sulfidity rate constant, reduced the screened yield. This was due to the increased degradation of cellulose. The decrease in viscosity confirmed this statement. Accordingly, the active alkali rate can be taken as $18 \%$. The yield was reduced by changing the cooking time from $75 \mathrm{~min}$ to 90 min (excluding D4) while keeping the active alkali rate and sulfidity constant. In this case, 75 min of cooking time was sufficient.

In this study, in general, the evaluation of the tensile, tear, and burst indices obtained during the cooking period of $75 \mathrm{~min}$ showed that some values had increased; however, most decreased when the time was increased to $90 \mathrm{~min}$. The reason is that long-term cooking causes the degradation of carbohydrates and a decrease in viscosity. In this case, a cooking time of 75 min would be appropriate.

The produced paper exhibited high opacity values and would be suitable for use as writing and printing paper. Excluding Group A, their Kappa values provided an easy-to-bleach feature, and if desired, these paper sheets could be easily bleached without damaging their mechanical properties.

Taking into account the screened yield and some mechanical and optical properties of the avocado wood pulp produced via the Kraft method, the ideal cooking conditions were: active alkali rate: $18 \%$, sulfidity rate: $22 \%$, cooking time: $75 \mathrm{~min}$. Using the Kraft method in the production of pulp from avocado wood enables cooking under more moderate conditions than with other hardwood types widely used in pulp production. Therefore, we believe that good results may be obtained from this kind of semi-chemical and mechanical production of pulp.

\section{REFERENCES \\ 5. LITERATURA}

1. Ajuziogu, G. C.; Nzekwe, U.; Chukwuma, H. I., 2010: Assessment of suitability of wood fibres of four Nigerian fruit trees for paper-making. Bio-Research, 8 (2): 679681.

2. Altunışık Bülbül, G.; Gençer, A., 2021: Determination of some chemical and morphological properties of avocado wood and researching its suitability for pulp production. Journal of Bartin Faculty of Forestry, 23 (1): 95-103. https://doi.org/10.24011/barofd.838203.

3. Arkadiusz, D.; den Jan, B.; Girma, G.; Techane, B.; Adamzyk, F., 2020: Economic analysis of the collection and transportation of pruned branches from orchards for energy production. Drewno, 63 (205): 125-140. https://doi.org/10.12841/wood.1644-3985.284.01.

4. Bayram, S.; Arslan, M. A.; Turgutoğlu, E., 2006. Development of avocado cultivation in Turkey, importance and some recommended varieties. Tagem Journals, 23 (2):1-13.

5. Casey, J. P., 1960: Pulp and paper chemistry and chemical technology, Vol. 1, $2^{\text {nd }}$ ed. New York: Wiley Interscience Publisher Inc. 
6. Demirkol, A., 2001: Tree Characteristics of some avocado varieties in antalya and their climatic affected conditions. Bahçe, 30 (1): 95-107.

7. Eroğlu, H., 1990: Paper pulp and paper physic. Karadeniz Technical University, 2. ed., No. 90. Trabzon, pp. 623.

8. Fuentes-Talavera, F. J.; Silva-Guzmán, J. A.; RodríguezAnda, R.; Lomelí-Ramírez, M. G.; Sanjuán-Dueñas, R.; Richter, H. G., 2011: Strength properties and natural durability of Avocado (Persea americana Mill.) branch wood. Madera y Bosques, 17 (1): 37-47.

9. Gencer, A., 2015: The utilization of Kiwi (Actinidia deliciosa) pruning waste for kraft paper production and the effect of the bark on paper properties. Drewno, 58 (194): 103-113.

https://doi.org/10.12841/wood.1644-3985.084.08.

10. Gençer, A.; Şirin, G.; Gül, H.; Özgül, U., 2013: Determination of the product conditions of pulp and paper from white mulberry (Morus alba L.) by kraft method. Bartın Orman Fakültesi Dergisi, 15 (1-2): 63-68.

11. Gençer, A.; Özgül, U., 2015: Determination of parameters for pulp production from common hazelnut (Corylus avellana L.) wood by the soda method. Turkish Journal of Forestry, 16 (2): 159-163.

12. Gençer, A.; Özgül, U., 2016: Utilization of common hazelnut (Corylus avellana L.) prunings for pulp production. Drvna industrija, 67 (2): 157-162. https://doi.org/10.5552/drind.2016.1529.

13. Gençer, A.; Gül Türkmen, H., 2016: Determination of paper production condition of wild cherry heartwood and sapwood. Bartın Orman Fakültesi Dergisi, 18 (1): 23-31.

14. Gençer, A.; Özgül, U.; Onat, S. M.; Gündüz, G.; Yaman, B.; Yazıc1, H., 2018: Chemical and morphological properties of apricot wood (Prunus armeniaca L.) and fruit endocarp. Bartın Orman Fakültesi Dergisi, 20 (2): 205 209.

15. Gençer, A.; Aksoy, H., 2017: Paper production from wild dogwood (Cornus australis L.) and the effect of bark on paper properties. Artvin Çoruh Üniversitesi Orman Fakültesi Dergisi, 18 (2): 186-191.

16. Gonzáles, Z.; Rosal, A.; Requejo, A.; Rodríguez, A., 2011: Production of pulp and energy using orange tree prunings. Bioresource Technology, 102 (19): 9330-9334. http://dx.doi.org/10.1016/j.biortech.2011.07.088.

17. Gülsoy, S. K.; Kılıç Pekgözlü, A.; Aktaş, A. C., 2015: Utilization of the pomegranate tree (Punica granatum L.) in the paper industry. Turkish Journal of Agriculture and Forestry, 39 (2): 295-299. https://doi.org/10.3906/tar-1404-105.

18. Kırc1, H., 2000: Kâğıt Hamuru Endüstrisi Ders Notları. Karadeniz Technical University Faculty of Forestry, Lecture Notes Publication, No. 63. Trabzon, pp. 274.

19. Odabaş Serin, Z.; Kılıç Penezoğlu, M., 2020a: Some features of olive (Olea europaea L.) wood growing in aydın and kahramanmaraş. Turkish Journal of Forest Science, 4 (2): 396-407. https://doi.org/10.32328/turkjforsci.787699.

20. Odabaş Serin, Z.; Kılıç Penezoğlu, M., 2020b: Chemical, physical and morphological properties of fig (Ficus cari- ca) wood. Avrupa Bilim ve Teknoloji Dergisi, 19: 843849.

21. Rydholm, S. A., 1965: Chemical pulping. Pulping processes. New York - London - Sydney: Interscience Publishers, pp. 1269.

22. Topaloğlu, E.; Öztürk, M.; Ustaömer, D.; Serdar, B., 2019: Wood anatomy properties of some fruit trees in the Eastern Black Sea Region and their evaluation in terms of paper production. Turkish Journal of Forestry Research, 6:2, 142-151. https://doi.org/10.17568/ogmoad.543568.

23. Topaloğlu, E.; Ustaömer, D., 2020: Investigation of physical, mechanical and surface properties of stem woods of some fruit trees. Düzce Üniversitesi Bilim ve Teknoloji Dergisi, 8 (1): 123-136.

https://doi.org/10.29130/dubited.574229.

24. Vargas, R. I.; Sanjuán-Dueñas, J. R.; Silva-Guzmán, J. A.; Rivera, P. J.; Fuentes-Talavera, F. J.; Richter, H. G., 2006: Properties of bleached pulp sheets of avocado wood (Persea americana Mill.) pulped by kraft and soda processes. Madera y Bosques, 12 (1): 29-36. https://doi.org/10.21829/myb.2006.1211248.

25. ***ISO 5267-1, 2012: Pulps - Determination of drainability. Part I: Schopper Reigler Method.

26. ***ISO 5269-2, 2013: Pulps - preparation of laboratory sheets for physical testing. Part 2: Rapid-Köthen method.

27. ***SCAN-CM 15-62, 1962: Viscosity of Cellulose.

28. ***TAPPI T 200 sp-01, 2001: Laboratory beating of pulp (Valley beater method).

29. ***TAPPI 236 om-06, 2006: The Kappa Number of Pulp.

30. ***TAPPI T 275 sp-02, 2002: Screening of pulp (Somerville-type equipment).

31. ***TAPPI T $402 \mathrm{sp}-03,2003$ : Standard conditioning and testing atmosphere for paper, board, pulp handsheets and related products.

32. ***TAPPI 403 om-02, 2002: Bursting strength of paper.

33. ***TAPPI 412 om-02, 2002: Moisture in pulp, paper and paperboard.

34. ***TAPPI 414 om-98, 1998: Internal tearing resistance of paper (Elmendorf-type method).

35. ***TAPPI T 494 om-01, 2001: Tensile properties of paper and paperboard (Using Constant Rate of Elongation Apparatus).

36. ***TAPPI T 525 om-02, 2002: Diffuse brightness of pulp $(\mathrm{d} / 0)$.

37. ***TAPPI T 519 om-02, 2002: Diffuse opacity of paper (d/0 paper backing).

\section{Corresponding address:}

\section{AYHAN GENÇER}

Bartin University

Forestry Faculty

Department of Forest Industry Engineering

74100 Bartin, TURKEY

e-mail: ayhangencer61@hotmail.com 